\title{
LEAD POISONING IN ANCIENT ROME
}

\begin{abstract}
Lead was known to the ancients from at least the $4^{\text {th }}$ millennium BC, but its use increased markedly during Roman times, to the extent that it became a health hazard. Mines and foundry furnaces caused air pollution; lead was extensively used in plumbing; domestic utensils were made of lead and pewter, and lead salts were used in cosmetics, medicines and paints. As a microbicide, lead was also used to preserve food. A grape juice concentrate (sapa) commonly used as a sweetener was prepared by preference in lead containers. Although Roman writers commented on the toxicity of lead, classic chronic lead poisoning was first described only in the $7^{\text {th }}$ century AD. Skeletal lead content increased significantly in the Roman era, but peaked at a level only $41-47 \%$ of that of modern Europeans. The authors thus suggest that chronic lead poisoning did not contribute significantly to the fall of the Roman Empire in the West.
\end{abstract}

\section{INTRODUCTION}

Lead, one of the seven metals known in ancient times, has been mined and used by man since at least the $4^{\text {th }}$ millennium BC (Waldron 1973:391; Steinbeck 1979:9; Drasch 1982:200). In the Graeco-Roman era the use of lead increased markedly (Woolley 1984:353-8). Environmental studies by French scientists have shown that lead contamination in ice precipitated in the polar regions dates back to approximately $500 \mathrm{BC}-\mathrm{AD} 300$, when lead pollution probably first became a significant health problem (Emsley 1991:14; Eliot 1995:132). Boutron, a French geologist, estimates that over the 800 years of GraecoRoman civilisation approximately 400 tons of lead were deposited in Greenland via rain and ice (Emsley 1991:14). Romans such as Vitruvius (De architectura viii.6.10 \& 11) and Pliny the Elder (Historia Naturalis ${ }^{1}$ xxxiv.50.167) recognised the toxicity of lead and its fumes, but chronic lead poisoning is surprisingly poorly documented in this period. Yet it has long been claimed that lead poisoning was common, even endemic. Authors such as Kobert (1909:103-19), Gilfillan (1965:53-60), Nriagu (1983b:661-3) and Woolley (1984:353-61) postulate that it played a major role in the eventual fall of the Roman Empire in the West in the

1 H.N. hereafter. 
$5^{\text {th }}$ century AD. This view is opposed by Needleman \& Needleman (1985:63-94), Gaebel (1983:431), Scarborough (1984:469, 470) and Drasch $(1952: 226,227)$, among others, who see the impact of lead pollution at the time as less significant.

This study will thus investigate the nature and scope of lead poisoning in ancient Rome in order to assess its effect upon the long-term development of the region and the course of its history.

\section{THE LEAD INDUSTRY IN ANCIENT ROME}

\subsection{Lead production}

From the $5^{\text {th }}$ millennium BC (Gilfillan 1965:55) lead has been mined from ore such as ceruse (lead carbonate, or white lead) and especially galena (lead sulphide). These ores also contain other metals such as silver and gold, and even arsenic (Waldron 1973:392; Nriagu 1983a: 113). Galena, in particular, contained significant amounts of silver and was obtained mainly from mines in Asia Minor, Spain, Sardinia and Britain (Waldron \& Wells 1979:111; Nriagu 1983a:107). The Laurion mine in Greece, famous above all for its silver, produced 300 parts of lead to every part of silver (Gilfillan 1965:55; Nriagu 1983a:107). Lead was also a minor by-product of the processing of copper ore (Nriagu 1983a:107).

Lead ore was processed to produce lead at foundries, usually situated in close proximity to mines. Except in Spain, these furnaces had short chimneys (only approximately $2,5 \mathrm{~m}$ tall). In the mining and foundry industries workers were exposed to continuous contact with lead and its fumes (Nriagu 1983a:108-11), and environmental pollution may be assumed to have been significant (Pliny H.N. xxxiv.49; xxxv.19; Xenophon Memorabilia 3.6; Vitruvius 8.3.6). Craftsmen producing lead products worked mainly in small workshops clustered around the foundries (Nriagu 1983a:112).

In the Roman era lead production made major strides. In the Bronze Age (2 100-1 200 BC) the mining of metals had caused little lead pollution, although lead had often been added to the alloys of copper and tin. In the Iron Age (1 200-50 BC) potential lead contamination still posed relatively little danger to human beings, until large-scale 
lead production commenced (Waldron \& Wells 1979:109-11). At its peak the Roman Empire probably used 80000 tons of lead annually (Woolley 1984:353-61). Needleman \& Needleman (1985:73) quote sources which estimate that annual lead production during the first two centuries AD amounted to approximately four kilograms per capita. This equates to two-thirds of the lead consumption of the United States in the 1970s! Nriagu (1983a:106) has calculated that lead production in the ancient world rose from 3170 kilotons a year in the Bronze period to 14310 kilotons in the Iron Age and to 14960 kilotons during the period of the Empire (50 BC-AD 500). During the years 500-1 000 production dropped again to 4250 kilotons.

\subsection{Known lead compounds}

Apart from lead as a metal and as ore, ceruse (mainly lead carbonate, known as white lead) and galena (mainly lead sulphide), the Romans were also familiar with a yellow intermediary product, litharge (lead oxide, known as yellow lead) (Dioscorides v.102; Waldron 1983:392), which was produced during the smelting process. It was sometimes used in the building industry (Nriagu 1983a:109). Ceruse was used industrially and sometimes medicinally (Pliny H.N. xxiv.50; Dioscorides v.103). Lead acetate (sugar of lead) was used both to sweeten and to preserve food and wine (Waldron \& Wells 1975:111). Pliny (H.N. xxiv.54.175) also refers to ceruse as lead acetate, which indicates a degree of confusion among the ancient writers concerning these compounds.

\subsection{The uses of lead}

The word "plumbing" is derived from the Latin plumbum, meaning lead. Lead pipes and lead seals on clay pipes were used extensively in plumbing, and aqueducts and reservoirs were lined with sheet lead (Vitruvius 8.3-11; Steinbeck 1979:9; Waldron \& Wells 1979:110; Needleman \& Needleman 1983:73). For example, 12000 tons of lead were used for the construction of a single pump unit in the aqueduct at Lyons (Waldron 1973:393).

Household containers and cooking implements also contained a great deal of lead. Bronze and copper pots were often lined with lead (or an alloy of lead and silver), to prevent the unpleasant taste of cop- 
per from tainting the food (lead, on the other hand, tended to impart a sweet taste). Pewter (an alloy of lead and tin) was also extensively employed for domestic utensils (Waldron 1973:393; Needleman \& Needleman 1985:74). Containers for wine and the equipment for the production of olive oil were often made of or lined with lead (Cato, De re rustica $\mathrm{cv}, \mathrm{lxvi}$ ). The wine fermentation process, too, often made use of casks or containers lined with lead (Cato cv). Lead glazing on earthenware vessels was rare, however (Needleman \& Needleman 1985: 76), and although types of flint glass may have been produced in ancient Mesopotamia (Adamson 1979:335), its popular use dates only from the $17^{\text {th }}$ century (Bennett 1991:7).

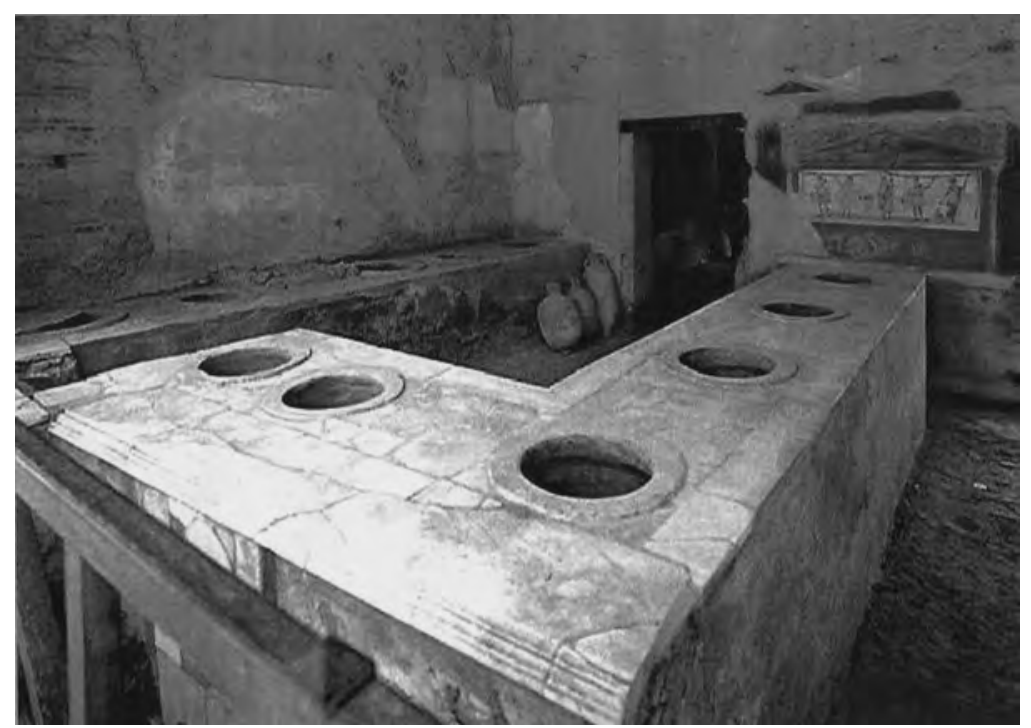

Figure 26: A tavern at Pompeii where wine heated in containers in the counter was served to passers-by.

Since sugar was unknown and honey relatively expensive, the Romans made much use of a concentrate of grape must as a sweetener. This was produced by boiling the young wine, preferably in copper pots, and 
was known as sapa or defrutum (Columella xii.19.20; cf. also Needleman \& Needleman 1985:74, 75). It was highly polluted by lead (Kobert 1909:107; Elsinger 1982:282), but was widely used as a sweetener for food, as a preservative for bottled fruit, and as a fermentation inhibitor (and a fungicide) in the wine industry (Waldron 1973:393; Nriagu 1983b:660). It was equally widely used to sweeten wine (Nriagu 1983b:660). Lead acetate (sugar of lead), produced by the action of acetic acid on lead, was also used as a sweetener for food and wine. The acetic acid was derived from wine vinegar made from mature wine (Waldron \& Wells 1979:111).

Lead compounds, especially ceruse (lead carbonate, or white lead) were used as face powders (Ovid, Medicamina faciei 73), salves and eye ointments, and also in white paint (Pliny, H.N. xxxiv.50; cf. also Needleman \& Needleman 1985:74, 76). Hopkins (1965:134) and Gilfillan (1965:57) are of the opinion that lead compounds were also used for contraception, and Dioscorides (v. 95, 100, 102, 103) recommends litharge (lead oxide, or yellow lead) for the treatment of certain skin diseases and facial wrinkles. The real medical value of lead has remained limited over the centuries, however.

Nriagu (1983a:105) has shown that the Romans would also have come into contact with lead in many other forms, including statues and ornaments, roofs and gutters, coins, standard weights, projectiles and other implements of war, as well as in the shipbuilding industry and the building industry in general.

\section{THE EFFECT OF LEAD ON THE HUMAN BEING}

\subsection{Metabolic effects}

Metabolically, lead has a wide-ranging toxic effect on human tissue. By blocking the enzyme actions which are essential to normal metabolism (mainly by the inhibition of sulpho-hydrilic radicals in enzymes), lead slows down the functioning of many bodily organs. Lead also has a special toxic affinity for certain tissues, like the liver, the kidneys, the haemopoetic system and the nervous system, but especially for bone tissue. Percutaneous absorption of lead is minimal, except in the case 
of organic lead compounds such as tetra-ethyl lead, found in modern times in leaded petrol. ${ }^{2}$ Significant absorption of lead can take place via the lungs and the alimentary canal. In adults, only about $8 \%$ of any lead orally ingested is absorbed, but in children the figure can be much higher, up to $50 \%$. By contrast, $30-40 \%$ of inhaled lead is absorbed by the lung tissue and $80-100 \%$ of it is then absorbed into the bloodstream (Drasch 1982:227). This absorbed lead is initially passed from the bloodstream to the liver and the kidneys, in particular. Most of it is excreted by the kidneys. In the course of time, the remaining lead is dispersed to other organs of the body, including the hair. Typically, however, more than $90 \%$ of the lead remaining in the body eventually accumulates in the bone tissue, where lead levels rise progressively until at least the age of 40 . The amount of lead in the skeleton is in direct proportion to the total lifelong absorption of lead. This lead is not toxic to the body, unless it returns to the bloodstream as a result of significant decalcification. Lead present in other body tissue, such as the kidneys, blood, muscles and nervous system, is dangerous in varying degrees. If present in high enough concentrations, it causes the typical clinical picture of lead poisoning (Goodman \& Gilman 1975:938-42; Grandjean 1978:304; Needleman \& Needleman 1985:78). There are individual differences, however, in how people react to comparable degrees of lead poisoning.

\subsection{The clinical picture of lead poisoning}

As we know today, lead poisoning may present as acute or chronic (Goodman \& Gilman 1975:940-2). An episode of acute poisoning may be followed by symptoms of chronic poisoning caused by the lead remaining in the body during the gradual process of excretion. Chronic lead poisoning may also present periodically alongside an acute symptom complex.

2 Cf. the article "Kommer oor lood in bloed van SA jeug" [Concern over lead in blood of SA youth] in Die Volksblad (1 November 1999), in which concern is expressed about the "unacceptably high level of lead" in the blood of South African children (particularly in Cape Town and environs) in comparison with that of their European and American peers. The main cause is the high levels of lead in the exhaust gasses of motor vehicles, as well as in the ground and the air around places where paint with a high lead content has been used. 


\subsubsection{Acute lead poisoning}

This is rare, and usually results from oral intake of soluble lead compounds. It is characterised by immediate abdominal pain; nausea and vomiting; a sore mouth and throat, accompanied by an acrid, metallic taste; thirst, and later diarrhoea. With large dosages, shock may set in, along with paraesthesia, pain, and muscle weakness, or even haemolytic anaemia with kidney failure. Death may ensue one or two days later.

\subsubsection{Chronic lead poisoning}

This characteristically presents with various symptom complexes: an abdominal syndrome with loss of appetite, a metallic taste in the mouth, a grey "lead line" on the gums in cases of poor oral hygiene, severe constipation and typical attacks of very severe abdominal colic; a neuromuscular syndrome characterised by peripheral paralysis (especially the typical "dropped wrist"); exhaustion, and diverse symptoms caused by lead encephalopathy, especially in the case of children, which may vary from vague learning problems, mental retardation, headache or deviant behaviour to delirium, convulsions and death (Grandjean 1978: 309-11). It can also present as a blood syndrome characterised by anaemia as a result of inhibited red cell development (the inhibition of haemosynthesis) or the manufacture of fragile red cells (haemolysis). Paleness without anaemia has also been described (Goodman \& Gilman 1975: 940). Among other things, gout can be caused by lead poisoning. This condition is known as Saturnine gout ${ }^{3}$ and is based on chronic kidney damage with an accumulation of uric acid and the deposition of urate crystals in and around the joints (Ball 1971:401-8; Nriagu 1983b:660-3; Weeden 1981:201-6).

\subsection{The archaeological determination of lead poisoning} In children, lead poisoning is often characterised by patterns of densification in bony tissue, identified by diagnostic radiology as "lead lines".

3 The name derives from the Middle Ages, when certain soils, elements and metals were given the names of planets according to their perceived nature. The technical name for lead was "Saturn", as it was astrologically associated with a slow, cold, sombre temperament. 
This technique has not yet been utilised by archaeologists, however (Waldron \& Wells 1979:115; Jarcho 1964:95).

The lead content of bones and teeth can be determined by means of atomic absorption spectrophotometric techniques and can serve as an indication of an individual's total lifelong exposure to lead. Possible contamination by lead from the surrounding soil may occur in exhumed skeletons (Drasch 1982:215-7; Waldron \& Wells 1979:113), but such contamination would appear to be minimal in soil conditions producing well-preserved skeletons (Waldron \& Wells 1979:108, 109). This technique for measuring lead content has other limitations which researchers must bear in mind: lead content represents the total lead burden and does not therefore indicate whether there were periodic poisoning peaks. (Acute clinical poisoning may occur periodically in individuals whose total lead burden is not particularly high.) Lead diffusion through the skeleton is not uniform, either — the skull, ribs and vertebrae, for example, reveal higher levels than the pelvic bone, the bones of the forearm (such as the ulna), and the teeth. For any given lead intake, the lead levels in bone are higher in children than in adults; bony lead content also increases with the passage of time. Ancient bones reveal a higher concentration of lead (as well as of calcium) than modern bones due to progressive desiccation and the destruction of the organic bone matrix. An adjustment formula taking the age of the adult into consideration is therefore necessary. There is no difference in bone lead content between men and women (Waldron \& Wells 1979: 103-8; Drasch 1982:215-26).

The lead content of hair can also indicate the systemic lead burden, but unlike bone, hair is constantly replaced. Thus, due to its the shortterm value, its archaeological use is limited (Grandjean 1978:313).

\section{THE INCIDENCE OF LEAD POLLUTION AND LEAD POISONING}

\subsection{Sources of pollution}

There is clear evidence of the exceptional extent of lead production and consumption in the Graeco-Roman era (Woolley 1984:353-61). According to Nriagu (1983a:105), lead production in Europe and the 
Mediterranean area during the $2^{\text {nd }}$ millennium $\mathrm{BC}$ increased tenfold, reaching a peak in the $1^{\text {st }}$ millennium $\mathrm{BC}$ and the period up to $\mathrm{AD} 500$, after which it dropped dramatically until AD 1000 to levels comparable with those of the $3^{\text {rd }}$ millennium BC. As has been indicated, lead contamination in the ice layers of Greenland dating from the period $500 \mathrm{BC}$ to AD 300 must have been caused by atmospheric pollution from the ore furnaces of ancient Rome (and Greece). The burden of lead in the ice is equivalent to $15 \%$ of the $20^{\text {th }}$ century's ice pollution due to leaded petrol (Emsley 1991:14).

Sources of lead pollution affecting the Roman populace may be summarised as follows:

(i) Domestic water supplies used mainly lead pipes and lead-lined canals. Hodge (1981:486-91) and others claim that this probably was an insignificant source of pollution because running water dissolves little lead and because calcium deposits in water pipes (from the hard water present in most of the developed areas of Rome) would have further reduced lead pollution. However, the Roman architect, Vitruvius (viii.6.10,11), tells us that water from clay pipes was cheaper and healthier than that from lead pipes. He also noted that water from wells and rivers situated near mines or foundries was often heavily polluted with lead (viii.3).

(ii) Lead-containing paints and lead compounds in medicines and cosmetics were potential sources of pollution when accidentally ingested. Percutaneous absorption of lead from such products would have been minimal, however (Goodman \& Gilman 1975:938-42).

(iii) The pollution of food, wine and olive oil as a result of their preparation in pewter or lead containers and the addition of sugar of lead or sapa were important sources of lead poisoning. Nriagu (1983b: 661) estimates that 50-60\% of the lead intake of an adult Roman freeman came from wine. Researchers who have prepared sapa from original recipes report lead levels of 700-1000 mg per litre (Kobert 1909:107; Elsinger 1982:282). Calculations based on the directions of Columella (12.20) and Cato (24.1) for the preparation of wine with added sapa, and on the assumption that a well-to-do Roman citizen would drink between one and two litres of wine a day (Nriagu 1983b:662; Needleman \& Needleman 1985:75), sug- 
gest that regular consumption of potentially fatal quantities of lead was highly possible (Needleman \& Needleman 1985:75). It is probable that the nobility and the well-to-do would have had a greater tendency to lead poisoning due to their greater access to sapa-sweetened food and wine, as well as to more contact with domestic utensils, paints, medications and cosmetics containing lead. Archaeological research into the North American colonial period has also shown that lead levels in bones there were higher in plantation owners than in workers (Aufderheide et al. 1981:285-91). Pewterware was probably used by the Roman middle class rather than the nobility, who would have eaten off silverware (Needleman \& Needleman 1985:76). Nriagu (1983b:661) estimates that the aristocracy of the Empire period consumed $250 \mathrm{mg}$ of lead a day, as against 35 $\mathrm{mg}$ for plebeians and $15 \mathrm{mg}$ for slaves. He compares this with current figures of 30-50 mg lead a day for the average urban adult in the USA and with the $45 \mathrm{mg}$ a day regarded by the World Health Organisation as the permissible maximum.

(iv) Workers in lead mines, foundries and lead production plants were most exposed to lead pollution. It has been estimated that approximately 80000 workers could have been involved annually at lead mines or foundries, and a further 60000 in the manufacturing industry (Nriagu 1983a:108). In the mines, hygiene was primitive but lead poisoning was probably limited due to the indissolubility of the lead sulphide in galena ore; more soluble lead carbonate from the rarer ceruse was potentially more dangerous. Protective material was worn over the head and face to prevent toxic inhalation (Nriagu 1983a:109). The foundry process, on the other hand, could have caused serious lead pollution in workers and those living in the area (Nriagu 1983a:108). Pliny the Elder (H.N. xxxiii.31) describes the fatal effects of foundry gases on both humans and animals. The pollution of water supplies in such areas by lead was also mentioned (Vitruvius 8.3). 


\subsection{Evidence of lead poisoning}

\subsubsection{The clinical picture}

The ancient writers were aware of the dangers of lead compounds. Dioscorides (v.9.103) writes that ceruse, taken internally, could be fatal, and that certain sweet wines could adversely affect the abdomen and the nerves; Pliny the Elder (H.N. xxxiv.50.167; 54.175; xiv.22) notes the poisonous nature of lead fumes, the toxicity of certain lead compounds, and the diverse effects of wine containing sapa on different people; Celsus (De Medicina v.27.10-12) refers to the poisonous nature of white lead; Vitruvius (viii.6, 10, 11) writes that lead pipes cause disease (but as an architect continues to prescribe lead plumbing).

Nicander, the Greek physician-poet of the $2^{\text {nd }}$ century BC, is generally credited with the first description of lead poisoning. His poem about a disease caused by ceruse (lead carbonate), translated by Major (1959:312), describes what could well be acute lead poisoning, with acute symptoms of abdominal discomfort, vomiting, a sore mouth with an acrid taste, painful muscles and progressive paralysis, involuntary eye movement, disturbance of balance, hallucination and finally death (if untreated).

It is noteworthy, however, that the clinical picture of chronic lead poisoning as we know it was not recognisably described in the period under discussion. Claims for complete or partial (but recognisable) descriptions of lead poisoning by Hippocrates (Hunter 1962:230; Sigerist 1936:605), Dioscorides (Waldron 1973:384), Vitruvius (Waldron 1973:394) and Pliny the Elder (Waldron 1973:394) cannot be verified by study of the primary sources. At best, certain symptoms may have been recognised. Gout was common in the Roman era and is well described by Hippocrates, who also indicates its association with alcohol and rich food. It is possible that we are dealing here, at least in part, with that variant of gout caused by lead (Nriagu 1983b:660).

The first recognisable description of chronic lead poisoning is that of Paul of Aegina, the Greek physician of the $7^{\text {th }}$ century AD. He describes an epidemic characterised by abdominal colic, paralysis without sensory disturbance, epilepsy, and high mortality (Major 1955:312). However, he does not associate the symptom complex with lead toxicity. 


\subsubsection{Archaeological findings}

The determination of bone lead levels relevant to this study has been performed by Grandjean (1978:304-6); there are extant Sudanese skeletons dating back as far as $3300 \mathrm{BC}$, prehistoric Danish remains (Waldron \& Wells 1979:102-15); skeletons from Britain, from the Roman occupation era (Aufderheide et al. 1981:285-91), remains from the North American colonial period (Drasch 1982:199-231), and skeletons from Peru (500-1 000 AD) and Europe (18 $8^{\text {th }}$ century BC to $20^{\text {th }}$ century AD).

The findings may be summarised as follows:

- If the Sudanese and Peruvian data are taken as providing "zero values" for lead pollution, then the levels of lead in bone from that time to the modern period may be described as having multiplied from twenty-fold (Drasch 1982:199) to a hundred-fold (Grandjean 1978:305).

- Despite wide intra-group variation, well-to-do communities demonstrate higher lead levels than the less well-off, and urban communities higher levels than rural populations.

- In occupied areas during the late Roman era, lead levels were at $41-47 \%$ of present-day European levels. After AD 500 the levels dropped to $13 \%$ of modern levels, but during the Middle Ages they increased again to approximately the same levels as those of ancient Rome.

- Lead levels in the Roman capital were not significantly higher than in European legionary cities such as the present-day Augsburg.

\section{DISCUSSION}

It is clear that the mining and use of lead in the ancient world increased immensely from the $2^{\text {nd }}$ millennium BC to about AD 500. Along with this, environmental lead pollution became a reality. One may ask to what extent lead pollution may have adversely affected humanity in general, and ancient Rome in particular. Since the beginning of the $20^{\text {th }}$ century, it has often been suggested that the fall of the Roman Empire was precipitated by chronic exposure to lead (Kobert 1909:103-19; Gilfillan 1965:53-60; Nriagu 1983b:660-3; Woolley 
1984:353-61). In essence, the argument is that clinical lead poisoning affected the aristocracy in particular, causing a drastic reduction in fertility and reproduction at that level. It could also have exacerbated general mortality rates for various reasons, thus reducing the numbers of the Roman leadership.

The question of just how serious a problem lead pollution was in Roman society is thus of central importance. Nriagu (1983a:105-16) and others have done calculations based on details about the Roman lifestyle, lead mining and foundries, plumbing (mainly in lead pipes or lead-lined canals and systems), cooking processes, and the wine industry in particular, as indicated above. These studies demonstrate that the aristocracy, above all, could well have developed severe systemic lead poisoning.

However, Scarborough (1984:469-75) and Needleman \& Needleman (1985:63-94) warn that calculations of lead consumption must be critically scrutinised. Although sapa prepared in leaden containers would indubitably have contained toxic levels of lead, the use of leaden containers was popular but not necessarily general. The exact amount of sapa added to wine was not standardised either, and we have no idea how often sapa was added, or which wines were treated in this way. Pliny the Elder claims that there were 185 different types of wine in his day. He writes with annoyance that true unsweetened wine has become unobtainable, even for the nobility (H.N. xiv.29). Thus, if sweetened wine is to be considered the main cause of lead poisoning (Nriagu 1983b: 661), toxicity in Pliny's day must have been high.

Gilfillan (1965:53-60) supports the hypothesis that lead poisoning caused lowered fertility, miscarriages and abortions among Roman women, and was in this way one of the reasons for the decline in the numbers of the Roman aristocracy from the $2^{\text {nd }}$ century BC. (Aristocratic family names such as Julius and Cornelius, for example, systematically disappear.) The role actually played by lead in pregnancy is unclear, however, and current evidence suggests that only toxic doses of lead can significantly influence pregnancy (Dilts \& Ahokas 1979: 940-6). The affected women would therefore have had to demonstrate the classic picture of lead poisoning — but no such condition is described. Needleman \& Needleman (1983:65-71) and Scheidel (1999: 
274 n. 57) argue convincingly that the disappearance of aristocratic family names does not necessarily indicate a decline in the number of noble families, but that the complex composition of the aristocracy was subject to constant change during the Empire, and that many other factors besides lead could have been responsible for the apparent decline in the numbers of the aristocracy and the reduction in family size.

If lead pollution was indeed a serious problem in ancient Rome, the question arises as to why the typical clinical picture of chronic lead poisoning was not described, while the toxicity of lead compounds was apparently realised. Nicander's poem from the $2^{\text {nd }}$ century $\mathrm{BC}$ describes what is in all probability acute lead poisoning, but only in the $7^{\text {th }}$ century AD did Paul of Aegina describe the characteristic symptom complex of chronic poisoning (without, however, associating it with the aetiology of lead). Vague descriptions of abdominal pain, along with muscular pain and debilitation, among other things, by Pliny the Elder and Vitruvius cannot be unquestioningly accepted as proof that the Romans knew about chronic lead poisoning. It is possible that the gout which was common in this period was a manifestation of sub-clinical lead poisoning, but the connection was not recognised at the time. Roman historians and scholars are renowned for the fact that disease is often not well documented (Retief \& Cilliers 1999:2). However, it seems logical to argue that the absence of recognisable descriptions of lead poisoning in the Roman era indicates that the clinical picture seldom actually occurred.

Indeed, archaeological evidence based on the determination of lead in skeletons confirms that the average lead burden of the population of ancient Rome was less than half that of modern Europeans (Drasch 1982:199-231). As has already been shown, this does not mean that episodes of clinical lead poisoning did not occur from time to time, or that lead poisoning could not have been endemic in certain regions of the Roman Empire. The archaeological sample is relatively small, and does not cover all areas. It nevertheless seems unlikely that the Roman populace could have suffered on a large scale from functionally significant clinical lead pollution. Well-to-do groups (such as the aristocracy) ingested more lead than the less well-to-do. The fact that Rome and Augsburg have comparable lead burdens indicates that exposure to lead pollution probably occurred throughout the Empire, and that the 
women of Rome would not have been more affected than those in the provinces. The British studies of Waldron \& Wells (1979:102-15) also confirm the widespread occurrence of pollution and that the skeletal lead burden in Britain was even higher than that in Rome. While lead pollution in ancient times resulted overwhelmingly from the oral ingestion of lead, probably supplemented by pulmonary contamination by lead fumes (mainly from foundries), modern pollution is mainly the result of inhalation of fumes from leaded petrol (Drasch 1982:226).

In conclusion, it could be argued that the increased lead production which began in the $2^{\text {nd }}$ millennium $\mathrm{BC}$ reached its zenith in ancient Rome. The accompanying lead pollution led to a drastic increase in the lead burden of the population, and in well-to-do communities in particular. Although clinical lead poisoning may well have occurred from time to time in certain areas and certain population groups, archaeological findings indicate that the average lead burden in the population was less than half that of a modern European living in the same area. The typical picture of chronic lead poisoning was not described until the $7^{\text {th }}$ century AD. It is thus unlikely that lead poisoning could have had enough impact to have played any significant role in the decline of the Roman Empire in the West or its eventual fall towards the end of the $5^{\text {th }}$ century AD. 
Lead poisoning in ancient Rome REFERENCES

\section{ADAMSON P B}

1979. Absorption of lead in ancient Mesopotamia. Medicina Nei Secoli (Rome) 16(3):333-7.

\section{Aufderheide A C, Neiman F D \& Wittmers L E}

1981. Lead in bone II: skeletal lead content as an indicator of lifetime lead ingestion and the social correlates in an archaeological population. American Journal of Physical Anthropology 55:285-91.

\section{BALL G V}

1971. Two epidemics of gout. Bulletin of the History of Medicine 45:401-8.

\section{BENNETT W I}

1991. Plumb brandy. Harvard Health Letter 16(6):7.

\section{CATO AND VARRO}

1934. On agriculture (transl. W.D. Hooper et al.). Cambridge, MA: Harvard University Press. Loeb Classical Library.

\section{Celsus}

1953. De Medicina (transl. W.G. Spencer). Cambridge, MA: Harvard University Press. Loeb Classical Library.

\section{Columella}

1979. On agriculture. Vol. III (transl. E.S. Foster \& E.H. Heffner). Cambridge, MA: Harvard University Press. Loeb Classical Library.

\section{DiegarT P (HRsG.)}

1909. Die Beiträge aus der Geschichte der Chemie. Dem Gedächtnis von Georg W. A. Kablbaum. Leipzig: [n.p].

\section{Dilts P V \& Ahokas R A}

1979. Effects of dietary lead and zinc on pregnancy. American Journal of Obstetrics and Gynecology 135(7):940-6.

\section{DIOSCORIDES}

2000. De materia medica. Being a Herbal with many other medicinal materials. A new indexed version in modern English. By T.A. Osbaldeston \& R.P.A. Woods. Johannesburg: Ibidis Press.

\section{DRASCH G A}

1982. Lead burden in prehistorical, historical and modern human bodies. The Science of the Total Environment 24:199-231.

\section{ELIOT J L}

1995. Lead pollution fouled ancient skies. National Geographic 187(6):732.

\section{ELSINGER J}

1996. Sweet poison. Natural History 105:48-52. 


\section{EMSLEY J}

1994. Ancient world was poisoned by lead. New Scientist 143:14.

\section{GAebel R E}

1983. Saturnine gout among Roman aristocrats. The New England Journal of Medicine 309(7): 431 .

\section{GILFILLAN S C}

1965. Lead poisoning and the fall of Rome. Journal of Occupational Medicine 7: 53-60.

\section{GOODMAN L S \& GILMAN A}

1975. The pharmacological basis of therapeutics. $5^{\text {th }}$ ed. New York: MacMillan.

\section{GRANDJEAN P}

1978. Widening perspectives of lead toxicity. Environmental Research 17:303-21.

\section{Hodge A T}

1981. Vitruvius, lead pipes and lead poisoning. American Journal of Archaeology 85:486-91.

\section{HOPKINS K}

1965. Contraception in the Roman Empire. Comparative Studies in Society and History 8:124-51.

\section{HunTer D}

1962. The diseases of occupation. London: Livingstone.

\section{JARCHO S}

1964. Lead in the bones of prehistoric lead-glaze potters. American Antiquity 30 (1):94-6.

\section{KOBERT R}

1909. Chronische Bleivergiftung im klassischen Altertum. In: P. Diegart (Hrsg.), Die Beiträge aus der Geschichte der Chemie. Dem Gedächtnis von Georg W A Kablbaum, Leipzig: [n.p]., pp. 103-19.

\section{MAJOR R H}

1959. Classic descriptions of disease. $3^{\text {rd }}$ ed. Springfield: C.C. Thomas.

\section{Needleman L \& Needleman D}

1985. Lead poisoning and the decline of the Roman aristocracy. Classical Views 29:64-94.

\section{NRIAGU J O}

1983a. Occupational exposure to lead in ancient times. The Science of the Total Environment 31:105-16.

1983b. Saturnine gout among Roman aristocrats. The New England Journal of Medicine 308(11):660-3. 


\section{Lead poisoning in ancient Rome}

\section{OvID}

1947. Art of love. Cosmetics et al. (transl. J.H. Mozley). Cambridge, MA: Harvard University Press. Loeb Classical Library.

\section{PLINY}

1952. Natural history (transl. H. Rackham). Cambridge, MA: Harvard University Press. Loeb Classical Library Vol. IX.

\section{Retief F P \& Cilliers L}

1999. Epidemies in antieke Rome en ander Mediterreense lande. Suid-Afrikaanse Tydskrif vir Natuurwetenskap en Tegnologie 18(1):17-23.

\section{SCARBOROUGH J}

1984. The myth of lead poisoning among Romans: an essay reviewed. Journal of the History of Medicine 39:469-75.

\section{SCHEIDEL W}

1999. Emperors, aristocrats, and the grim reaper: towards a demographic profile of the Roman elite. Classical Quarterly 49(1):254-81.

\section{SIGERIST H E}

1936. Historical background of industrial and occupational disease. Bulletin of the New York Academy of Medicine 12:600-8.

\section{STEINBECK R T}

1979. Lead ingestion in ancient times. Palaeopathology Newsletter (Detroit) 27:911.

\section{VITRUVIUS}

1956. On architecture (transl. F. Granger). Cambridge, MA: Harvard University Press. Loeb Classical Library.

\section{WALDRON H A}

1973. Lead poisoning in the ancient world. Medical History 17:391-9.

\section{WALDRON T \& Wells C}

1979. Exposure to lead in ancient populations. Transactions and studies of the College of Physicians of Philadelphia 1:102-15.

\section{WEEDEN R P}

1981. Punch cures the gout. Journal of the Medical Society of New Jersey 78(3):201-6.

\section{WoOLley D E}

1984. A perspective of lead poisoning in antiquity and the present. Neurotoxico$\log y$ 5(3):353-61.

\section{XENOPHON}

1959. Memorabilia and Oeconomics (transl. E.C. Marchant). Cambridge, MA: Harvard University Press. Loeb Classical Library. 